\title{
NORMAL FAECAL PORPHYRIN VALUES IN BABIES
}

\author{
BY \\ W. M. POLITZER AND I. KESSEL \\ From the South African Institute for Medical Research and the Department of Paediatrics, University of \\ the Witwatersrand and the Queen Victoria Maternity Hospital, Johannesburg, South Africa
}

(RECEIVED FOR PUBLICATION APRIL 15, 1957)

Normal faeces contain both coproporphyrin and protoporphyrin in very small quantities. These arise in part as by-products from haem synthesis which are excreted via the bile into the gut, in part from degradation of ingested haem, and possibly also in part by bacterial synthesis in the intestine. In adults normal values (Barnes, 1957) are: coproporphyrin, $0-15 \mu \mathrm{g}$. per g. dry weight ; and protoporphyrin, $0-45 \mu \mathrm{g}$. per g. dry weight.

The purpose of this investigation was to establish normal values in babies from birth up to 1 year of age. Only one reference in the literature has been found to porphyrin determinations in babies and children (Fokina, 1947), but, whereas Fokina has estimated average faecal elimination values per 24 hours, these values are expressed as micrograms per gramme dry weight and therefore the two investigations are not strictly comparable.

\section{Material}

Random specimens of stool were collected from babies on ordinary hospital diet, with no history of porphyrinuria and suffering from diseases or conditions not thought to influence porphyrin metabolism. Determinations were repeated several times during the patients' stay in hospital. The specimens of stool were yellow to khaki in colour; none was dark brown or black.

The age and sex distribution of the babies are shown in Table $I$.

TABLE I

AGES AND SEX OF BABIES INVESTIGATED

\begin{tabular}{|c|c|c|c|c|c|c|}
\hline \multicolumn{4}{|c|}{ Age } & $\begin{array}{l}\text { No. of } \\
\text { Patients }\end{array}$ & Male & Female \\
\hline $\begin{array}{l}0-6 \text { months } \\
7-12\end{array}$ & .. & .. & $\begin{array}{l}. \\
.\end{array}$ & $\begin{array}{r}11 \\
9\end{array}$ & $\begin{array}{l}5 \\
3\end{array}$ & $\begin{array}{l}6 \\
6\end{array}$ \\
\hline
\end{tabular}

\section{Method}

Rimington's method (Barnes, 1956) of partitioning the porphyrins and his quantitative analysis was used.
Extraction of Coproporphyrin.-The weighed faeces were dried in an oven at $105^{\circ}$ to $110^{\circ} \mathrm{C}$. One gramme of the specimen was treated with acetic acid and extracted with ether. This extraction was repeated until no orange-red fluorescence could be detected. The pooled extract was washed with saturated sodium acetate and $0.005 \%$ iodine. The ether solution was then treated as follows. For the extraction of coproporphyrin, shake as above using successive amounts of $0.1 \mathrm{~N}$ hydrochloric acid until no further red fluorescent material is removed.

Extraction of Protoporphyrins (Non-copropor. phyrins). - This was carried out similarly with $1.5 \mathrm{~N}$ hydrochloric acid. The two extracts were made up to convenient volumes and read on a Beckman spectrophotometer at $430,380 \mathrm{~m} \mu$ and at their peak values. The results were expressed in micrograms per gramme dry weight of faeces.

\section{Results}

The findings in both age groups are shown in Fig. 1. It will be seen that except in two cases there was no wide variation in results, and amounts of both coproporphyrin and protoporphyrin were lower than those in normal adults (Barnes, 1956). This lowered output can be accounted for by the meatless diet consumed by the infants. In two cases, however, protoporphyrin results much higher than the others were obtained. Both babies were suffering from infection, one (aged 9 months) from infected burns and the other (aged 12 months) from periorbital cellulitis.

During the course of this investigation one child (aged 2 months) contracted acute laryngo-tracheobronchitis; whilst the coproporphyrin remained unchanged (1.0 and $1.1 \mu \mathrm{g}$. per $\mathrm{g}$. dry weight) the protoporphyrin rose sharply from 3.0 to $32.5 \mu \mathrm{g}$. per g. dry weight. With the exception of these three cases, estimations repeated on several occasions gave similar results. It can be concluded that the range for normal values for both coproporphyrin and protoporphyrin in infants is 0 to $10 \mu \mathrm{g}$. per g. dry weight. 


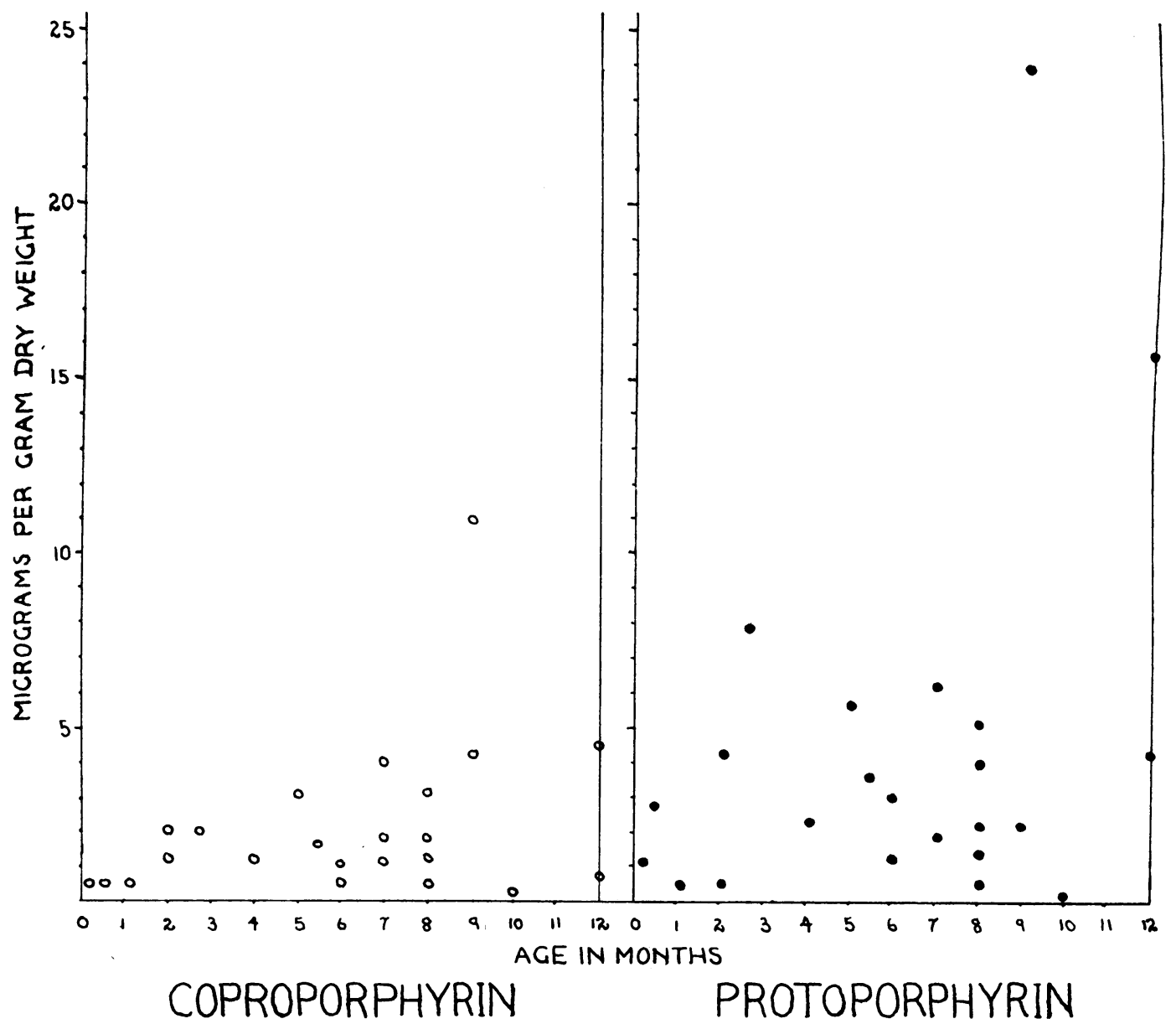

Fig. 1

\section{Summary}

Coproporphyrin and protoporphyrin levels in babies were determined in order to establish normal values.

We wish to thank the Director of the Institute for his interest and for facilities for carrying out this work, Dr. H. D. Barnes for his help and encourage- ment, and Mrs. N. Stevens for her technical assistance.

\section{REFERENCES}

Barnes, H. D. (1956). The Incidence of Various Types of Porphyria in South African Bantu as Compared with that in the White Population. Ph.D. the.is, University of London. (1957). Personal communication.

Fokina, T. V. (1947). Pediatrija, No. 6, p. 36. Abstracted in Chem. Abstr., 42, 8928 (1948). 